\title{
Risk assessment during preventive home visits among older people
}

\author{
Astrid Fjell ${ }^{1,2}$ \\ Berit Seiger Cronfalk ${ }^{1,3}$ \\ Nina Carstens ${ }^{4}$ \\ Arvid Rongve 5,6 \\ Lars M Rosseland Kvinge ${ }^{7}$ \\ Åke Seiger ${ }^{8}$ \\ Knut Skaug9 \\ Anne-Marie Boström ${ }^{1,2,10}$ \\ 'Department of Neurobiology, \\ Care Sciences and Society, Division \\ of Nursing, Karolinska Institutet, \\ Stockholm, Sweden; ${ }^{2}$ Department of \\ Nursing, Western Norway University \\ of Applied Sciences, Haugesund, \\ Norway; ${ }^{3}$ Department of Nursing \\ Sciences, Ersta Sköndal Bräcke \\ University College, Stockholm, \\ Sweden; ${ }^{4}$ Hospital Pharmacies \\ Enterprise, Western Norway, \\ Bergen, Norway; ${ }^{5}$ Department of \\ Research and Innovation, Helse \\ Fonna, Haugesund Hospital, \\ Haugesund, Norway; ${ }^{6}$ Institute of \\ Clinical Medicine, University of \\ Bergen, Bergen, Norway; ${ }^{7}$ FOUSAM, \\ Western Norway University of \\ Applied Sciences, Haugesund, Norway; \\ ${ }^{8}$ Department of Neurobiology, \\ Care Sciences and Society, Division \\ of Clinical Geriatrics, Karolinska \\ Institutet, Stockholm, Sweden; \\ ${ }^{9}$ Department of Medicine, Helse \\ Fonna, Haugesund Hospital, \\ Haugesund, Norway; ${ }^{10}$ Theme Aging, \\ Karolinska University Hospital, \\ Huddinge, Sweden
}

Correspondence: Astrid Fjell Department of Nursing, Western Norway University of Applied Sciences, Bjørnsonsgate 45, 5528 Haugesund, Norway

Tel +47 9II5 3947

Email astrid.fjell@ki.se
This article was published in the following Dove Press journal: Journal of Multidisciplinary Healthcare

Background: Preventive home visits (PHV) may contribute to identify risks and needs in older people, and thereby delay the onset of functional decline and illness, otherwise often followed by home care or admission to hospital or nursing homes. There is a need to increase knowledge about which factors are associated with different risk areas among older people, so that the PHV questionnaire focuses on relevant tests and questions to make the PHV more specific and have a clear focus and purpose.

Objective: The objective of this study was to examine associations between five kinds of risks: risk of falls, malnutrition, polypharmacy, cognitive impairment, and risk of developing illness and factors related to lifestyle, health, and medical diagnoses among older people living at home. Methods: A cross-sectional study design was applied. PHV were conducted by nurses among 77-year-old people in an urban municipality and among $\geq 75$-year-old people in a rural municipality. A questionnaire including tests and a risk assessment score for developing illness was used. Descriptive and inferential statistics including regression models were analyzed.

Results: The total sample included 166 persons. Poor perceived health was associated with increased risk of developing illness and risk of fall, malnutrition, and polypharmacy. Lifestyle and health factors such as lack of social support, sleep problems, and feeling depressed were associated with risk of developing illness. Risk of falls, malnutrition, polypharmacy, and cognitive impairment were also associated with increased risk of developing illness. None of the independent factors related to lifestyle, health, or medical diagnosis were associated with risk of cognitive impairment.

Conclusion: Poor perceived health was associated with health-related risks in older persons living at home. Preventive health programs need to focus on social and lifestyle factors and self-reported health assessment to identify older people at risk of developing illnesses.

Keywords: preventive home visits, older adults, risk assessment, developing illness, perceived health, social factors, logistic regression analysis, lifestyle

\section{Introduction}

A goal for preventive health interventions conducted by healthcare professionals for older people living at home is to strengthen their ability to avoid or delay functional decline, frailty, or risks. ${ }^{1}$ Common risks in older persons living at home are falls, malnutrition, polypharmacy, and cognitive impairment. ${ }^{2}$ A current strategy to prevent or delay these risks is to carry out preventive home visits (PHV) in order to identify risk scenarios pertaining to age-related health issues. In Norway, the government supported a strategy to develop PHV programs in primary health care to identify older people at risk of developing illness. ${ }^{3}$ As a result of this strategy, a PHV model with the 
overall aim of identifying risks of developing illness among older people in the western part of Norway was developed. ${ }^{4}$

\section{Background}

The population older than 65 years of age is growing. Increased age is associated with various types of risks, causing negative consequences such as declining health, decreased ability to live independently, or premature death. ${ }^{2,5,6}$ This may lead to correspondingly increased dependence on societal resources for older persons. ${ }^{7,8}$ The PHV model used in this study, developed by Cronfalk et al, focuses on five risk areas: falls, malnutrition, polypharmacy, cognitive impairment, and developing illness. ${ }^{4}$ These risk areas have strong associations with the older people's life and general health. A strong impact on how health and quality of life are perceived by older people is the risk of falls. Major risk factors are reduced balance and gait, a previous history of falls, and polypharmacy. Other risk factors are female gender and visual and cognitive impairment. ${ }^{9}$ Malnutrition among older people affects quality of life negatively and reduces the ability to perform everyday activities. General health decline, poor self-reported health status, polypharmacy, and cognitive impairment are all factors that have an impact on older people's nutritional status. ${ }^{10}$ Polypharmacy is associated with increased risk of falls, disability, cognitive impairment, delirium, hospitalization, and mortality for older people. ${ }^{11}$ Cognitive impairment among older people is increasing and early detection is the key aim of dementia policies in the Western world. ${ }^{12}$ Risk factors associated with cognitive impairment and dementia are advanced age, smoking, malnutrition, polypharmacy, inactivity, hypertension, vascular conditions like stroke and cerebral hemorrhages, obesity, and diabetes mellitus as well as socioeconomic aspects such as low educational level. Development of illness is a threat for older people. With a growing population of older people, complex diseases and conditions are likely to result in repeated hospital visits and increased need of municipal services. Increase in age is associated with declining health and makes older people especially susceptible to various illnesses and functional decline. ${ }^{6}$

To conclude, numerous factors are associated with risks of falls, malnutrition, polypharmacy, cognitive impairment, and the risk of developing illness among older people. Factors associated with these risks could be categorized into demographic, lifestyle, and health factors including medical diagnoses. ${ }^{2,13}$ By identifying risks and the associated factors in older people and taking appropriate action, functional decline may be postponed and survival improved.
PHV has been described as a care pathway to identify risks and needs among the older population. ${ }^{8}$ It is an intervention which has been tested and evaluated worldwide, especially in Europe, North America, and Japan. It is legally practiced in Australia, Denmark, and United Kingdom. ${ }^{14}$ In Norway, "The Coordination Reform"3 was embarked upon by the Norwegian government in 2012, aiming at increasing municipalities' responsibility for primary health care including nursing homes, home care, and general practitioners. ${ }^{3}$ To accommodate the challenges within "The Coordination Reform", the government supported a strategy to develop PHV programs in primary health care to identify risks for developing illness among older people. Systematic reviews show that PHV could reduce the number of hospital admissions, increase cost effectiveness and quality of life, improve mental and psychical health outcomes, and reduce mortality. ${ }^{14-16}$ Behm et al showed in their study that a combination of PHV and group meetings postponed progression of frailty in older adults. ${ }^{17}$

Despite considerable use of PHV, ongoing discussions revolve around what the focus at home visits should be to best identify different risks among older people. ${ }^{14,18}$ Cronfalk et al developed a PHV model Health Team for the Elderly in western Norway using a team-based approach. ${ }^{4}$ Health team nurses used a questionnaire that included validated tests and instruments associated with various age-related risks and questions concerning health, illness, and medication. The questionnaire was developed using a Comprehensive Geriatric Assessment approach, which is described as suitable for recognizing risks and needs in the older population. ${ }^{19}$ The questionnaire consists of a final section with additional questions to assess the risk of developing illness using 12 subscales. The subscales were used as a total score classification at four risk levels where the levels indicated the degree of risk of developing illness. Level 1 indicates no immediate risk of developing illness and level 4 indicates high risk for developing illness. The questionnaire has been evaluated and its feasibility has been tested. ${ }^{4}$ In the feasibility study using this questionnaire in a sample of 166 older persons, 130 (78.3\%) persons were categorized as level $1,27(16.3 \%)$ persons as level 2, nine (5.4\%) persons as level 3 , and no person was categorized into level 4. In total, 36 (22\%) persons were identified as having an increased risk of developing illness (level 2-4) using this risk assessment score. ${ }^{4}$

Thus, identifying risks among older people using PHV may contribute to better health, independence at home, and less use of healthcare services. However, there is a knowledge gap in the literature about the focus and content of PHV to best achieve risk prevention by older people. ${ }^{18,20}$ There is a need to increase knowledge about which factors are associated with different 
risk areas among older people, so that the PHV questionnaire focuses on relevant tests and questions to make the PHV more specific and have a clear focus and purpose. In this study, the PHV questionnaire included assessment of five areas of risks: falls, malnutrition, polypharmacy, cognitive impairment, and developing illness, which made it possible to examine associations between these five risks. Therefore, the objective was to examine associations between five kinds of risks: risk of falls, malnutrition, polypharmacy, cognitive impairment, and risk of developing illness (dependent variables) and factors related to lifestyle, health, and medical diagnoses (independent variables) among older people living at home.

\section{Methods Design}

A cross-sectional study design was used to meet the objective of the study.

\section{Setting and sample}

Two settings were included: an urban and a rural municipality in Norway. Convenience sampling was used as the procedure of the municipalities. All 77-year-old people $(n=177)$ in one urban municipality with $\sim 45,000$ inhabitants and all $\geq 75$-year-old people ( $n=82$ ) in one rural municipality with almost 1,000 inhabitants were invited. In the rural municipality, people aged $\geq 75$ years were included because the number of 77-year-old inhabitants was too small and the number of participants would be much smaller if only they were to be included. In total, 259 persons were invited to participate in the study. Inclusion criteria were living at home, able to answer questions, and understand written information in the Norwegian language. Exclusion criteria included older people living in a nursing home and/or those who were unable to understand the Norwegian language (both reading and writing). All participants received an invitation letter with information about the study. A project administrator telephoned them and arranged appointments for a PHV if the older person wanted to participate. ${ }^{4}$

\section{Data collection}

In the present study, a questionnaire based on a study of Säätelä and Fagerström ${ }^{21}$ was used (for details, see Cronfalk et $\mathrm{al}^{4}$ ). The questionnaire included a substantial number of questions and validated tests focusing on falls (Bergs Balance Scale $[\mathrm{BBS}]$ ), ${ }^{22}$ nutrition (Mini Nutrition Assessment), ${ }^{23}$ polypharmacy, and cognitive impairment (Mini-Cog), ${ }^{24}$ in addition to questions regarding demographics, lifestyle including social networks, health including health assessments, and medical diagnoses including medications. ${ }^{4}$ In this study, polypharmacy was defined as the use of five or more different medications. The questions and response options are presented in Table 1.

The final section of the questionnaire consists of a multidimensional assessment for the risk of developing illness including 12 subscales: declining health, declining functional level, loneliness, risk of falling, recently moved, declining sight/hearing, loss of close one, spouse is chronically ill, recently discharged from hospital, mental or cognitive problems, polypharmacy, and nutrition. Each subscale scores $0-5$ points. The total score of the subscales is used as a classification at four levels: risk level 1; 0-24 points, risk level 2 ; 25-36 points, risk level 3; 37-48 points, and risk level $4 ; 49-60$ points. The levels indicate the degree of risk of developing illness and level 1 indicates the lowest risk of developing illness. The inter-rater reliability analysis of the assessments of the scores for the risk of developing illness was deemed to be acceptable with a Cohen's Kappa value of 0.912. The development and feasibility testing of the questionnaire have been described by Cronfalk et al. ${ }^{4}$

The PHV was conducted by a health team nurse as a structured interview using the questionnaire described earlier. In total, four trained nurses completed data collection in the two municipalities. At the end of the visit the older person was encouraged to contact the nurse if she or he had any questions regarding the visit or had more information to add. On average, a visit took 1.5 hours to complete. ${ }^{4}$

\section{Dependent and independent variables}

Five dependent variables assessing risks of falls, malnutrition, polypharmacy, cognitive impairment, and the risk of developing illness were used. The values for the cutoff score for falls, malnutrition, and cognitive impairment were chosen using the cutoff score for each instrument. The cutoff score for polypharmacy was set to five medications. The cutoff score for the risk of developing illness was set to risk level 2-4 in the risk assessment tool (Table 1).Twenty independent variables (explanatory variables) representing four categories, demographic, lifestyle, health, and medical diagnoses, were chosen due to previous research studies presented in the background. ${ }^{2,13}$ The response alternatives were dichotomized except for age and social support, and for the risk variables when used as independent variables. An overview of the dependent and independent variables is presented in Table 1.

\section{Data analysis}

Data were analyzed using SPSS program, version 23 (IBM Corporation, Armonk, NY, USA). Descriptive statistics were 
Table I Description of the dependent and independent variables

\begin{tabular}{|c|c|c|c|}
\hline $\begin{array}{l}\text { Dependent } \\
\text { variable }\end{array}$ & Instrument/question & Response options & $\begin{array}{l}\text { Dichotomized/reference } \\
\text { values }\end{array}$ \\
\hline Risk of falls & BBS & $\begin{array}{l}10-12 p=\text { no risk } \\
\leq 9 p=\text { risk of fall }\end{array}$ & $\begin{array}{l}\text { No risk/0 } \\
\text { Increased risk/I }\end{array}$ \\
\hline Risk of malnutrition & MNA-SF & $\begin{array}{l}I 2-14 p=\text { no risk } \\
\leq I I P=\text { risk of malnutrition }\end{array}$ & $\begin{array}{l}\text { No risk/0 } \\
\text { Increased risk/I }\end{array}$ \\
\hline Risk of polypharmacy & $\begin{array}{l}\text { How many prescribed } \\
\text { drugs do you take? }\end{array}$ & $\begin{array}{l}\text { Number of prescribed } \\
\text { medications }\end{array}$ & $\begin{array}{l}\text { No polypharmacy: } \leq 4 \\
\text { medications } / 0 \\
\text { Polypharmacy: } \geq 5 \\
\text { medications/I }\end{array}$ \\
\hline $\begin{array}{l}\text { Risk of cognitive } \\
\text { impairment }\end{array}$ & Mini-Cog & $\begin{array}{l}4-5 p=\text { no risk } \\
\leq 3 p=\text { risk of cognitive } \\
\text { impairment }\end{array}$ & $\begin{array}{l}\text { No risk/0 } \\
\text { Increased risk/I }\end{array}$ \\
\hline $\begin{array}{l}\text { Risk of developing } \\
\text { illness }\end{array}$ & Risk assessment score & $\begin{array}{l}0-24 p=\text { level I: no immediate } \\
\text { risk of developing illness } \\
25-36 \mathrm{p}=\text { level } 2 \text { : some risk of } \\
\text { developing illness } \\
37-48 \mathrm{p}=\text { level } 3 \text { : increased } \\
\text { risk of developing illness } \\
49-60 \mathrm{p}=\text { level } 4 \text { : high risk of } \\
\text { developing illness }\end{array}$ & $\begin{array}{l}\text { No risk (level I)/0 } \\
\text { Increased risk (levels 2-4)/I }\end{array}$ \\
\hline $\begin{array}{l}\text { Independent } \\
\text { variable (named) }\end{array}$ & Instrument/question & Response options & $\begin{array}{l}\text { Dichotomized/reference } \\
\text { values }\end{array}$ \\
\hline \multicolumn{4}{|l|}{ Demographics } \\
\hline Age & What is your birth date? & Years & $\begin{array}{l}\text { Used as a continuous } \\
\text { variable }\end{array}$ \\
\hline Gender & Which gender are you? & Male/female & \begin{tabular}{|l|} 
Male/0 \\
Female/I
\end{tabular} \\
\hline Education & $\begin{array}{l}\text { What education do you } \\
\text { have? }\end{array}$ & $\begin{array}{l}\leq 7 \text { years/elementary school/ } \\
\text { middle school/finishing } \\
\text { secondary school/high school/ } \\
\text { folk high school/craftmans } \\
\text { education/trade school/ } \\
\text { university/other }\end{array}$ & $\begin{array}{l}\text { College (trade school, high } \\
\text { school, university)/0 } \\
\text { No college (folk high } \\
\text { school/handy craft/trade } \\
\text { school/7 years/elementary } \\
\text { school/middle school/ } \\
\text { secondary school/others)// }\end{array}$ \\
\hline Marital status & $\begin{array}{l}\text { What is your marital } \\
\text { status? }\end{array}$ & $\begin{array}{l}\text { Married/cohabitant/alone/ } \\
\text { divorced/widow(er) }\end{array}$ & \begin{tabular}{|l|} 
Partner (married, \\
cohabitant) $/ 0$ \\
Single (alone, divorced, \\
widow[er])/I \\
\end{tabular} \\
\hline \multicolumn{4}{|l|}{ Lifestyle } \\
\hline Social support & OSLO 3 - SSS & $\begin{array}{l}3-5 p=\text { much support } \\
6-8 p=\text { some support } \\
9-14 p=\text { lack of support }\end{array}$ & $\begin{array}{l}\text { Used as a continuous } \\
\text { variable }\end{array}$ \\
\hline Exercise & $\begin{array}{l}\text { How often do you } \\
\text { exercise? (minimum } 30 \\
\text { minutes duration so } \\
\text { that you are warm and } \\
\text { slightly out of breath) }\end{array}$ & $\begin{array}{l}\text { Rare/I-3 times a month/I-3 } \\
\text { times a week/4-6 times a } \\
\text { week/daily }\end{array}$ & $\begin{array}{l}\text { Often (4-6 times a week, } \\
\text { daily)/0 } \\
\text { Seldom (I-3 times a week, } \\
\text { I-3 times a month, rare)/I }\end{array}$ \\
\hline Smoking & Do you smoke? & Yes/no/no, but smoked earlier & $\begin{array}{l}\text { No smoking (no, no, but } \\
\text { smoked earlier) } / 0 \\
\text { Smoking/I }\end{array}$ \\
\hline Alcohol & Do you use alcohol? & Yes/no & $\begin{array}{l}\text { No use of alcohol/0 } \\
\text { Use of alcohol// }\end{array}$ \\
\hline External activities & $\begin{array}{l}\text { How often are you } \\
\text { away from home? }\end{array}$ & $\begin{array}{l}\text { Rare/I-3 times a week/4-6 } \\
\text { times a week/daily/several } \\
\text { times a day }\end{array}$ & $\begin{array}{l}\text { Often (several times a day, } \\
\text { daily, 4-6 times a week)/0 } \\
\text { Few (rare, I-3 times a } \\
\text { week)/I }\end{array}$ \\
\hline
\end{tabular}

(Continued) 
Table I (Continued)

\begin{tabular}{|c|c|c|c|}
\hline $\begin{array}{l}\text { Independent } \\
\text { variable (named) }\end{array}$ & Instrument/question & Response options & $\begin{array}{l}\text { Dichotomized/reference } \\
\text { values }\end{array}$ \\
\hline \multicolumn{4}{|l|}{ Health } \\
\hline Vision & $\begin{array}{l}\text { How would you } \\
\text { describe your vision? }\end{array}$ & $\begin{array}{l}\text { Excellent/good/somewhat } \\
\text { impaired/reduced/visually } \\
\text { impaired }\end{array}$ & $\begin{array}{l}\text { Good (excellent and } \\
\text { good) } / 0 \\
\text { Reduced (somewhat } \\
\text { impaired, reduced, visually } \\
\text { impaired)/I }\end{array}$ \\
\hline Hearing & $\begin{array}{l}\text { How would you } \\
\text { describe your hearing? }\end{array}$ & $\begin{array}{l}\text { Excellent/good/somewhat } \\
\text { impaired/reduced/hearing } \\
\text { impaired }\end{array}$ & $\begin{array}{l}\text { Good (excellent and } \\
\text { good) } / 0 \\
\text { Reduced (somewhat } \\
\text { impaired, reduced, hearing } \\
\text { impaired)/I }\end{array}$ \\
\hline Sleep problems & $\begin{array}{l}\text { Do you have sleep } \\
\text { problems? }\end{array}$ & Nolyes & $\begin{array}{l}\text { No/0 } \\
\text { Yes/I }\end{array}$ \\
\hline Pain & Do you have pain? & Nolyes & $\begin{array}{l}\text { No/0 } \\
\text { Yes/l }\end{array}$ \\
\hline Feeling depressed & $\begin{array}{l}\text { Positive Life Orientation } \\
\text { Scale } \\
\text { Item f: Are you } \\
\text { depressed/sad? }\end{array}$ & $\begin{array}{l}\text { Seldom or never/sometimes/ } \\
\text { often or always }\end{array}$ & $\begin{array}{l}\text { No (seldom or never) } / 0 \\
\text { Yes (sometimes, often or } \\
\text { always)/l }\end{array}$ \\
\hline Perceived health & $\begin{array}{l}\text { SF 36: item I } \\
\text { How do you rate your } \\
\text { health? }\end{array}$ & $\begin{array}{l}\text { Excellent/very good/good/fair/ } \\
\text { poor health }\end{array}$ & $\begin{array}{l}\text { Good (excellent/very good, } \\
\text { good)/0 } \\
\text { Poor (fair/poor health)// }\end{array}$ \\
\hline \multicolumn{4}{|l|}{ Medical diagnosis } \\
\hline Hypertension & $\begin{array}{l}\text { Do you have } \\
\text { hypertension? }\end{array}$ & No/yes & $\begin{array}{l}\mathrm{No} / 0 \\
\mathrm{Yes} / \mathrm{I}\end{array}$ \\
\hline Hypercholesterolemia & $\begin{array}{l}\text { Do you have } \\
\text { hypercholesterolemia? }\end{array}$ & No/yes & $\begin{array}{l}\text { No/0 } \\
\text { Yes/I }\end{array}$ \\
\hline Eye disease & $\begin{array}{l}\text { Do you have eye } \\
\text { disease? }\end{array}$ & No/yes & $\begin{array}{l}\text { No/0 } \\
\text { Yes/I }\end{array}$ \\
\hline Arthrosis & Do you have arthrosis? & No/yes & $\begin{array}{l}\text { No/0 } \\
\text { Yes/I }\end{array}$ \\
\hline Cancer & Do you have cancer? & No/yes & $\begin{array}{l}\text { No/0 } \\
\text { Yes/I }\end{array}$ \\
\hline \multicolumn{4}{|c|}{ Risk factors (used in the analyses with risk of developing illness) } \\
\hline Risk of falls & BBS & $\begin{array}{l}10-12 p=\text { no risk } \\
\leq 9 p=\text { risk of fall }\end{array}$ & $\begin{array}{l}\text { Used as a continuous } \\
\text { variable }\end{array}$ \\
\hline Risk of malnutrition & MNA-SF & $\begin{array}{l}12-14 p=\text { no risk } \\
\leq 1 \mathrm{I}=\text { risk of malnutrition }\end{array}$ & $\begin{array}{l}\text { Used as a continuous } \\
\text { variable }\end{array}$ \\
\hline Risk of polypharmacy & $\begin{array}{l}\text { How many prescribed } \\
\text { drugs do you take? }\end{array}$ & $\begin{array}{l}\text { Number of prescribed } \\
\text { medications }\end{array}$ & $\begin{array}{l}\text { Used as a continuous } \\
\text { variable }\end{array}$ \\
\hline $\begin{array}{l}\text { Risk of cognitive } \\
\text { impairment }\end{array}$ & Mini-Cog & $\begin{array}{l}4-5 p=\text { no risk } \\
\leq 3 p=\text { risk of cognitive } \\
\text { impairment }\end{array}$ & $\begin{array}{l}\text { Used as a continuous } \\
\text { variable }\end{array}$ \\
\hline
\end{tabular}

Abbreviations: BBS, Bergs Balance Scale; MNA-SF, Mini Nutrition Assessment - Short Form.

used to present percentages and means. Student's $t$-test and chi-square tests were conducted to compare the two samples of persons identified for the risk of developing illness and no risk of developing illness.

Associations between the independent variables on demographic, lifestyle, health, and medical diagnoses and the dependent variables on risks of fall, malnutrition, poly- pharmacy, cognitive impairment, and the risk of developing illness score were explored using logistic regression adjusted models. Logistic regression analysis was conducted because the distribution of the four dependent variables, risks of falls, malnutrition, cognitive impairment, and risk for developing illness, score was skewed. ${ }^{25}$ The model was constructed by enter method and was adjusted for confounding variables 
sex, age, and education. In the adjusted regression analyses for risk of developing illness, the variables for risks of falls, malnutrition, polypharmacy, and cognitive impairment were also included and in the analyses these variables were not dichotomized, but were used as continuous data level (Table 1). Significance level in the adjusted model was set at $P<0.05$.

\section{Ethical approval}

This study was approved by the Inspectorate with the Norwegian Social Science Data Services A/S NSD (no 29153). The participants signed a form for informed consent.

\section{Results}

\section{Description of sample}

The sample included 166 of the 259 invited persons (response rate $60 \%$ ). Data from one participant were inconclusive and therefore excluded from the overall analysis. The Mini-Cog test had a screening question: "Do you find yourself having impaired memory?" Only if the person replied yes, was he/ she offered the opportunity to take the test. Therefore, only 106 persons completed this specific test.

The majority were women and the mean age of the total sample was 79 years. A large part of the sample had no college education and about half were single (Table 2). There were no significant differences regarding demographic variables between the group that was at risk of developing illness and the one without this risk.

Regarding lifestyle, $72 \%$ reported exercising seldom and $57 \%$ used alcohol. There was one significant difference between the two groups. People with the risk of developing illness reported less social support than those with no risk.

Of the total sample, 55\% reported pain, 35\% reported poor health, $34 \%$ had sleep problems, and $24 \%$ felt depressed. Furthermore, $52 \%$ were diagnosed with hypertension and $45 \%$ with hypercholesterolemia. There were significant differences between the two groups. Persons with the risk of developing illness reported to a higher extent reduced hearing, feeling depressed, and poor perceived health than those without this risk (Table 2).

\section{Risk assessment}

Results from the risk assessments are presented in percentage and mean values in Table 3. In total, 20 (13\%) persons were identified with risk of falls. For the total sample, BBS mean value was 11.1 . Twenty (12\%) persons were identified with risk of malnutrition and for the total sample the Mini Nutrition Assessment mean value was 13.1. Polypharmacy (five or more medications) was found in 57 (34\%) persons. For the

Table 2 Characteristics of the sample

\begin{tabular}{|c|c|c|c|c|c|}
\hline & $\mathbf{N}$ & Total & $\begin{array}{l}\text { Risk of developing } \\
\text { illness, } n=36\end{array}$ & $\begin{array}{l}\text { No risk of developing } \\
\text { illness, } n=130\end{array}$ & $P$-value \\
\hline \multicolumn{6}{|l|}{ Demographics } \\
\hline Age, mean (SD) & 166 & $78.7(3.3)$ & $79(3.5)$ & $79(3.3)$ & 0.620 \\
\hline Female (\%) & 166 & $96(58)$ & $18(50.0)$ & $78(60.0)$ & 0.282 \\
\hline No college (\%) & 166 & $130(78)$ & $30(83.3)$ & $100(76.9)$ & 0.409 \\
\hline Single (\%) & 166 & $80(48)$ & $15(41.7)$ & $65(50.0)$ & 0.376 \\
\hline \multicolumn{6}{|l|}{ Lifestyle } \\
\hline Social support, mean (SD) & 165 & $6.5(2.1)$ & $7.1(2.0)$ & $6.3(2.0)$ & 0.034 \\
\hline Seldom exercise (\%) & 163 & $117(72)$ & $30(83.3)$ & $87(68.5)$ & 0.081 \\
\hline Smoking (\%) & 166 & $26(16)$ & $6(16.7)$ & $20(15.4)$ & 0.851 \\
\hline Use of alcohol (\%) & 166 & $94(57)$ & $17(47.2)$ & $77(59.2)$ & 0.198 \\
\hline Few external activities (\%) & 166 & $28(16.9)$ & $8(22.2)$ & $20(15.4)$ & 0.332 \\
\hline \multicolumn{6}{|l|}{ Health } \\
\hline Reduced vision (\%) & 166 & $30(18)$ & $9(25.0)$ & $21(16.2)$ & 0.222 \\
\hline Reduced hearing (\%) & 164 & $63(38.4)$ & $19(52.8)$ & $44(34.4)$ & 0.045 \\
\hline Sleep problems (\%) & 166 & $56(34)$ & $17(47.2)$ & $39(30.0)$ & 0.053 \\
\hline Pain (\%) & 166 & $92(55)$ & $22(6 I . I)$ & $70(53.8)$ & 0.438 \\
\hline Feeling depressed (\%) & 166 & $39(24)$ & $14(38.9)$ & $25(19.2)$ & 0.014 \\
\hline Poor perceived health (\%) & 166 & $58(35)$ & $21(58.3)$ & $37(28.5)$ & 0.001 \\
\hline \multicolumn{6}{|l|}{ Medical diagnosis } \\
\hline Hypertension (\%) & 166 & $87(52)$ & $20(55.6)$ & $67(5 \mid .5)$ & 0.669 \\
\hline Hypercholesterolemia (\%) & 166 & $75(45)$ & $13(36.1)$ & $62(47.7)$ & 0.217 \\
\hline Eye disease (\%) & 166 & $45(27)$ & II (30.6) & $34(26.2)$ & 0.599 \\
\hline Arthrosis (\%) & 166 & $34(20)$ & $8(22.2)$ & $26(20.0)$ & 0.770 \\
\hline Cancer (\%) & 166 & $27(16)$ & $7(19.4)$ & $20(15.4)$ & 0.559 \\
\hline
\end{tabular}


total sample, the mean value was 3.9 medications. Among the 106 participants who completed the Mini-Cog test, 30 (28\%) were identified with the risk of cognitive impairment. There were significant differences between the two groups for these four variables all pointing in the same direction, which was, persons with the risk of developing illness had increased risks of falls, malnutrition, polypharmacy, and cognitive impairment (Table 3 ).

\section{Associated factors for risk of falls, malnutrition, polypharmacy, cognitive impairment, and risk of developing illness}

The regression analyses were adjusted for gender, age, and education. Poor perceived health was highly significantly associated with increased risk of falls, malnutrition, polypharmacy, and the risk of developing illness (Table 4). Risks of falls, malnutrition, polypharmacy, and cognitive impairment were associated with increased risk of developing illness as well as lack of social support, sleep problems, and feeling depressed. None of the five most common medical diagnoses (hypertension, hypercholesterolemia, eye disease, arthrosis, and cancer) were associated with the risk of developing illness.

Increased risk of falls was associated with the following independent variables: no use of alcohol, pain, and not having hypercholesterolemia. Increased risk of malnutrition was only associated with poor perceived health. Increased risk of polypharmacy was associated with the following independent variables: no use of alcohol, pain, hypertension, and hypercholesterolemia. None of the independent factors were associated with the risk of cognitive impairment.

\section{Discussion}

The objective of this study was to examine factors associated with the risk of falls, malnutrition, polypharmacy, cognitive impairment, and risk of developing illness. One key finding was that poor perceived health was associated with increased risks of falls, malnutrition, polypharmacy, and risk of developing illness. This finding is consistent with other studies, where poor perceived health was a risk factor for malnutrition, ${ }^{26}$ falls, ${ }^{27,28}$ and increased risk of polypharmacy. ${ }^{29}$ Even though a strong association was identified between poor perceived health and risks in the present study, Sherman et al have reported that some older people with various health problems perceived their health to be good or very good. ${ }^{30}$

Increased risk of developing illness was, as expected, associated with risks of falls, malnutrition, polypharmacy, and cognitive impairment, which indicates that seniors are particularly vulnerable to these risks. ${ }^{2}$ Therefore, it is important to focus on these four areas to delay illness and improve health and quality of life for seniors when using PHV. ${ }^{31,32}$ Furthermore, lifestyle factors such as lack of social support and factors regarding health such as having sleep problems and feeling depressed were also associated with the risk of developing illness. Our findings are in line with previous research findings revealing that lifestyle and social factors are associated with a healthier life with fewer diseases among older persons. ${ }^{33}$ Loneliness has been identified to be a strong predictor for higher risk of mortality among older adults. ${ }^{34}$ Interestingly, none of the medical diagnoses were associated with the risk of developing illness in the adjusted regression models, which indicates that the focus on PHV needs to include questions about lifestyle and perceived health.

Thirteen percent of the participants in our study were found to be at risk of falls. This is comparable to the findings of Dahlin-Ivanoff et al, who identified an increased risk of falls in $18 \%$ of older people living at home within the same age group and same assessment tool (BBS) as our

Table 3 Risk assessments in percentage and mean values for persons identified with risks of falls, malnutrition, polypharmacy, and cognitive impairment for the total sample, and comparison between persons with and without risk of developing illness

\begin{tabular}{|c|c|c|c|c|c|}
\hline Risk for & $\mathbf{N}$ & $\begin{array}{l}\text { Total, } \\
n=166\end{array}$ & $\begin{array}{l}\text { Risk of developing } \\
\text { illness, } n=36\end{array}$ & $\begin{array}{l}\text { No risk of developing } \\
\text { illness, } n=130\end{array}$ & $P$-value \\
\hline Falls (\%) & 160 & $20(13)$ & $10(30.3)$ & $10(7.9)$ & 0.001 \\
\hline BBS, mean (SD) & & II.I (I.5) & $10.1(1.9)$ & II.4 (I.3) & $<0.001$ \\
\hline Malnutrition (\%) & 166 & $20(12)$ & II (30.6) & $9(6.9)$ & $<0.001$ \\
\hline MNA-SF, mean (SD) & & I3.I (I.7) & $12.2(2.5)$ & $13.4(1.3)$ & $<0.001$ \\
\hline Polypharmacy (\%) & 166 & $57(34)$ & $15(4 I .7)$ & $42(32.3)$ & 0.295 \\
\hline No of medications, mean (SD) & & $3.9(2.4)$ & $4.8(3.0)$ & $3.7(2.2)$ & 0.040 \\
\hline Cognitive impairment (\%) & 106 & $30(28)$ & $17(73.9)$ & $13(15.7)$ & $<0.001$ \\
\hline Mini-Cog, mean (SD) & & $3.8(1.4)$ & $2.4(1.5)$ & $4.2(1.1)$ & $<0.001$ \\
\hline
\end{tabular}

Note: Data shown as $\mathrm{n}(\%)$ unless indicated otherwise.

Abbreviations: BBS, Bergs Balance Scale; MNA-SF, Mini Nutrition Assessment - Short Form. 


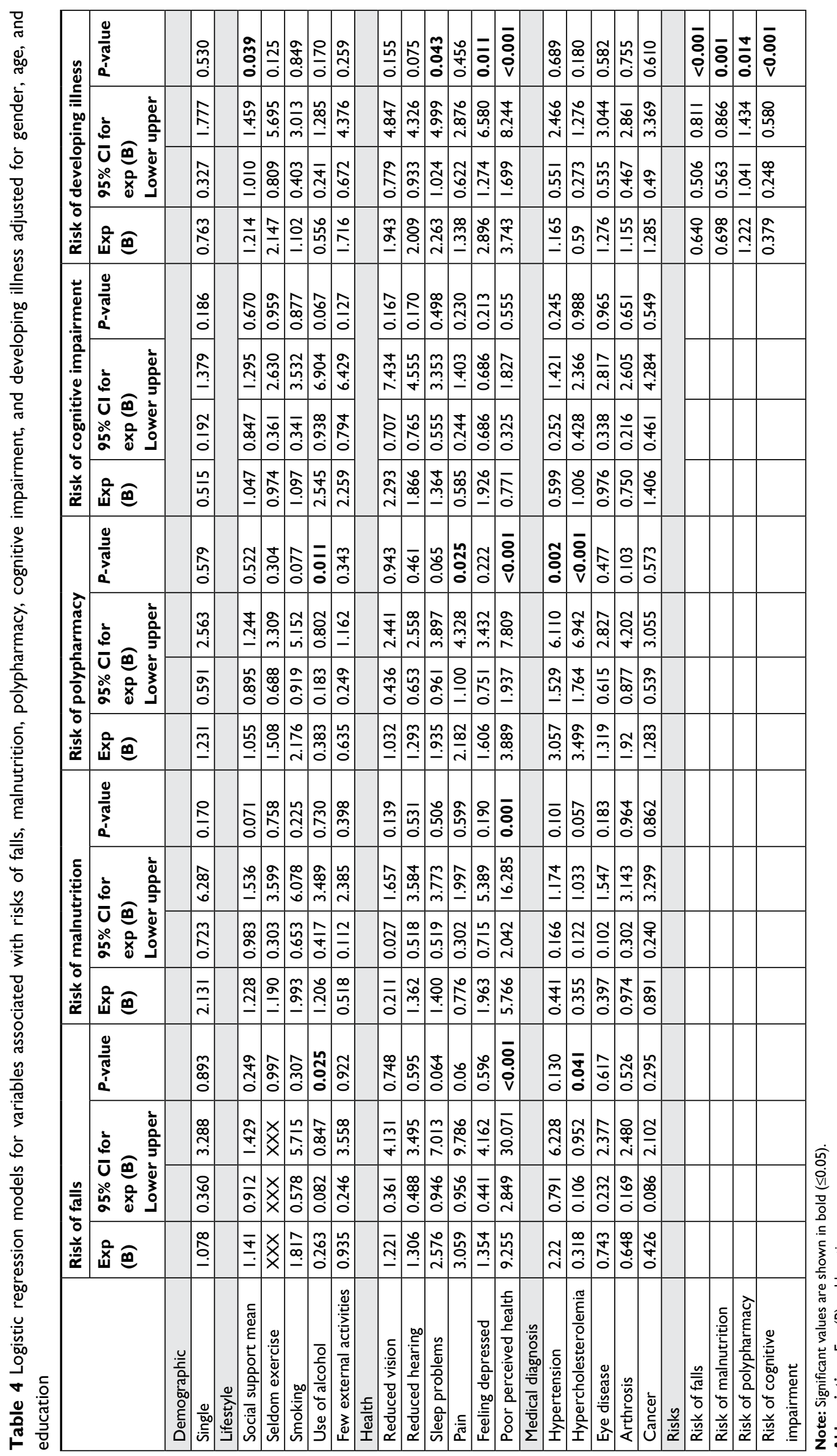


study. ${ }^{35}$ Another interesting finding was that risk of falls was associated with no use of alcohol. Usually, use of alcohol is associated with falls. ${ }^{9}$ A plausible explanation is that older people knew that they were at risk of falls and therefore did not use alcohol (or should not) for fear of falling.

The prevalence for risk of malnutrition was $12 \%$. Cereda et al conducted a systematic review and meta-analysis of the prevalence of malnutrition among older people across various healthcare settings including 240 studies, of which 58 were performed in community settings. ${ }^{36}$ The meta-analysis of the community studies showed that $27 \%$ had a risk of malnutrition. However, the prevalence in the community studies varied between $0 \%$ and $77 \%$. A Norwegian study, with nearly the same age group of participants as in the present study, also identified that $13.5 \%$ were at risk of malnutrition, ${ }^{37}$ which supports our findings.

Polypharmacy was identified in $35 \%$ of the total sample. In a Swedish PHV study among 75-year-olds, $42.5 \%$ had polypharmacy (used five or more drugs). ${ }^{38} \mathrm{~A}$ notable finding was that no use of alcohol was associated with increased risk for polypharmacy. In a group of home dwelling persons over 80 years, $58 \%$ had polypharmacy ( $\geq 5$ medications) and it was found that those who did not use alcohol had a higher risk for polypharmacy. ${ }^{39}$ Wauters et al suggest that older people who are prescribed many medications have several diseases, which in turn might lead to less participation in social activities providing an arena for drinking alcohol. ${ }^{39}$ Another explanation could be that older people with many medications do not drink alcohol because several medications, in particular pain medications, are associated with side effects in combination with the use of alcohol.

Finally, the prevalence of cognitive impairment was 28\% among the 106 persons who participated in the MiniCog test. Previous international studies have estimated the overall prevalence of mild cognitive impairment (MCI) in persons $\geq 60$ years to vary between $12 \%$ and $18 \%$, and in people $\geq 70$ years the overall prevalence of MCI was found to be $16 \%$ in a population-based study in Minnesota, USA. ${ }^{40}$ The participants in this study were older and therefore a larger proportion of them with cognitive challenges seems reasonable. Thus, the prevalence of risk of falls, malnutrition, polypharmacy, and cognitive impairment seems to be in line with previous studies in this age group.

None of the independent variables in this sample were associated with risk of cognitive impairment, even when well-known variables such as educational level, smoking, inactivity, and hypertension were assessed. A possible explanation might be the smaller sample size in this analysis as the participants were asked a screening question of whether they had memory problems and some of those who said no might have been in denial of their symptoms. ${ }^{41}$ In future PHV studies, all participants should be offered the Mini-Cog test or other tests for cognitive status without a screening question to ensure that people who might be at risk are allowed an appropriate assessment.

In this group of older persons living at home, approximately one fifth were identified to be at risk of developing illness using our risk assessment instrument. ${ }^{4}$ In previous studies that have assessed the prevalence of the geriatric syndrome frailty, $\sim 10 \%$ of persons aged $\geq 65$ years and as much as $50 \%$ of persons aged $\geq 80$ years have been identified as frail. ${ }^{42}$ Although the assessment for risk of developing illness has not been developed to identify frailty we believe that the instrument has the potential to identify older people's risk of developing illness and thereby to be an important tool in PHV models using a Comprehensive Geriatric Assessment approach. Early identification of poor health and functional decline and implementation of interventions to promote health and prevent illness may contribute to a better outcome such as better health and functional status and reduced hospital admissions for older persons. ${ }^{2}$

Machón et al investigated factors associated with selfreported health in older independent people. ${ }^{29}$ Factors associated with low perceived health were comorbidity, polypharmacy, sleeping problems, malnutrition, and lack of leisure activities. In our study, poor perceived health was associated with the increased risk of developing illness and also with increased risks of falls, malnutrition, and polypharmacy; therefore, it could be discussed whether the question about perceived health should be used as a screening question at a PHV. In the feasibility study the time used to conduct a PHV was on average 108 minutes. ${ }^{4}$ To save healthcare costs future research studies should examine whether a question about perceived health should be used as a screening question for persons who are offered a PHV. The idea to use a two-step approach to identify vulnerable older people has been further emphasized by Saliba et al, ${ }^{43}$ who included a question about self-reported health among 12 other questions in the development of the instrument VES-13. Self-reported health was one of the factors that predicted risk of functional decline and death. ${ }^{43}$ The findings from our study also raise questions of whether the PHV questionnaire should be shortened, and if so which of 
the questions and tests should be included. Future research needs to critically evaluate questions and tests that should be included in a PHV. One possibility may be that the older person answers some of the questions prior to the PHV using a web survey or other mobile applications. Using this approach, the health team nurse could focus on the most appropriate assessments at the PHV.

\section{Strengths and limitations}

The strengths of this study include the high response rate and the use of validated instruments for assessing health-related issues. The questionnaire also consists of a final section with additional questions to assess the risk of developing illness among older people. However, further studies are required to fully evaluate this strategy.

Even if $40 \%$ declined participation, maybe a PHV did not seem relevant for older persons, which is a common reason to reject $\mathrm{PHV}^{44,45}$ In the feasibility study, the people who declined participation reported that they felt too healthy to receive a $\mathrm{PHV}^{4}$

Participants from the rural municipality were aged $\geq 75$ years and some were older than 90 years, which may give a higher prevalence for risk of developing disease and other risk areas, as this is associated with increasing age. However, there were no significant differences comparing the levels of risk of developing illness between the two municipalities. ${ }^{4}$

This study is limited to one region in a Norwegian context. However, many of the findings are comparable with other PHV studies like Lagerin et $\mathrm{al}^{38}$ and Sherman et al; ${ }^{45}$ so, the results should be applicable to PHV models in countries or regions other than Norway.

The health team nurses were trained to conduct the PHV and to assess the older persons. There were few missing data except for the risk assessment for cognitive impairment. As previously described, the Mini-Cog test was preceded by a screening question about whether the person had memory problems or not. The response was the person's subjective experience, and therefore some participants with declining health might also have had cognitive impairments. This problem might have had an impact on the reliability of the data collected in this study. The assessment tool for the risk of developing illness contained the independent variables we analyzed in the regression analyses and therefore we expected these to be significantly associated with the risk score. However, it is still relevant to measure the relative impact from the different factors. We did not assess the quality of interpersonal relations, previously identified as the single most important factor for good perceived health in older people. ${ }^{46}$ Due to the skewed distribution of four of the five dependent variables, logistic regression models were used. ${ }^{25}$ A larger study is needed to confirm the findings from this study.

\section{Conclusion}

Poor perceived health was associated with health-related risks in older persons living at home. Lifestyle and health factors were associated with increased risk of developing illness. The prevalence of risks of falls, malnutrition, polypharmacy, and cognitive impairment was in line with previous studies. As poor perceived health was a factor most strongly associated with health-related risks in older persons living at home, this variable should be studied as a possible screening question to identify persons who are in most need of a PHV. To use perceived health as a screening question may increase the benefits of PHV for the society.

\section{Implications for clinical practice}

This study reveals the need to use questionnaires and tests which focus on assessing various aspects of older persons' health when conducting PHV. Questions concerning lifestyle and social factors such as social support, feeling depressed, and sleep problems should be included in PHV as these questions provide further information that may help to identify risks of developing illness. If these factors are identified, appropriate interventions can be tested and evaluated. However, the findings from this study indicate that nurses conducting PHV should ask the older person about selfperceived health, as that question was strongly associated with the risks of ill health.

\section{Acknowledgments}

We wish to thank all participants and the Swedish National Graduate School for Competitive Science on Ageing and Health for contributing to the research environment and to spur reflections and discussions of academic and methodological questions. We also wish to thank Jörg Assmus for statistical support. The study received financial support from the regional collaboration, Helsetorgmodellen, Haugesund, Norway.

\section{Author contributions}

$\mathrm{AF}, \mathrm{AMB}, \mathrm{AR}$, and BSC: study design and data analysis. AF: data collection. LMRKK, NC, KS and ÅS: study design. All authors took part in drafting the article or revising it critically for important intellectual content; and agreed on the final version of the manuscript. 


\section{Disclosure}

The authors report no conflicts of interest in this work.

\section{References}

1. Lacas A, Rockwood K. Frailty in primary care: a review of its conceptualization and implications for practice. BMC Med. 2012;10(1):4.

2. Stuck AE, Moser A, Morf U, et al. Effect of health risk assessment and counselling on health behaviour and survival in older people: a pragmatic randomised trial. PLoS Med. 2015;12(10):e1001889.

3. Norwegian Ministry of Health and Care Services. The coordination reform proper treatment - at the right place and right time. Oslo: Norwegian Ministry of Health and Care Services; 2009. Available from: https://www.regjeringen.no/contentassets/d4f0e16ad32e4bbd8d8ab5 c21445a5dc/en-gb/pdfs/stm200820090047000en_pdfs.pdf. Accessed October 11, 2018.

4. Seiger Cronfalk B, Fjell A, Carstens N, et al. Health team for the elderly: a feasibility study for preventive home visits. Prim Health Care Res Dev. 2017;18(3):242-252.

5. Beaton K, Mcevoy C, Grimmer K. Identifying indicators of early functional decline in community-dwelling older people: a review. Geriatr Gerontol Int. 2015;15(2):133-140.

6. Clegg A, Young J, Iliffe S, Rikkert MO, Rockwood K. Frailty in elderly people. Lancet. 2013;381(9868):752-762.

7. Morley JE, Vellas B, van Kan GA, et al. Frailty consensus: a call to action. J Am Med Dir Assoc. 2013;14(6):392-397.

8. Rechel B, Grundy E, Robine J-M, et al. Ageing in the European Union. Lancet. 2013;381(9874):1312-1322.

9. Ambrose AF, Paul G, Hausdorff JM. Risk factors for falls among older adults: a review of the literature. Maturitas. 2013;75(1):51-61.

10. Fávaro-Moreira NC, Krausch-Hofmann S, Matthys C, et al. Risk Factors for Malnutrition in Older Adults: A Systematic Review of the Literature Based on Longitudinal Data. Adv Nutr. 2016;7(3):507-522.

11. Fried TR, O'Leary J, Towle V, Goldstein MK, Trentalange M, Martin DK. Health outcomes associated with polypharmacy in communitydwelling older adults: a systematic review. J Am Geriatr Soc. 2014;62(12):2261-2272.

12. Mukadam N, Cooper C, Kherani N, Livingston G. A systematic review of interventions to detect dementia or cognitive impairment. Int $J$ Geriatr Psychiatry. 2015;30(1):32-45.

13. Lim SS, Vos T, Flaxman AD, et al. A comparative risk assessment of burden of disease and injury attributable to 67 risk factors and risk factor clusters in 21 regions, 1990-2010: a systematic analysis for the Global Burden of Disease Study 2010. Lancet. 2012;380(9859):2224-2260.

14. Liimatta H, Lampela P, Laitinen-Parkkonen P, Pitkala K. Effects of preventive home visits on older people's use and costs of health care services: A systematic review. Eur Geriatr Med. 2016;7(6): $571-580$

15. Frese T, Deutsch T, Keyser M, Sandholzer H. In-home preventive comprehensive geriatric assessment (CGA) reduces mortality - a randomized controlled trial. Arch Gerontol Geriatr. 2012;55(3) 639-644.

16. Tourigny A, Bédard A, Laurin D, et al. Preventive Home Visits for Older People: A Systematic Review. Can J Aging. 2015;34(4):506-523.

17. Behm L, Eklund K, Wilhelmson K, et al. Health promotion can postpone frailty: results from the RCT elderly persons in the risk zone. Public Health Nurs. 2016;33(4):303-315.

18. Mayo-Wilson E, Grant S, Burton J, Parsons A, Underhill K, Montgomery P. Preventive home visits for mortality, morbidity, and institutionalization in older adults: a systematic review and meta-analysis. PLoS One. 2014;9(3):e89257.

19. Ekdahl AW, Sjöstrand F, Ehrenberg A, et al. Frailty and comprehensive geriatric assessment organized as CGA-ward or CGA-consult for older adult patients in the acute care setting: A systematic review and metaanalysis. Eur Geriatr Med. 2015;6(6):523-540.
20. Tøien M, Heggelund M, Fagerström L. How do older persons understand the purpose and relevance of preventive home visits? A study of experiences after a first visit. Nurs Res Pract. 2014;2014:1-8.

21. Säätelä Saf L, Fagerström L. GERDA-projektet - tvärvetenskaplig forskning om äldres livsvillkor över gränserna. Vård $i$ Focus. 2006;23:27-29.

22. Berg KO, Wood-Dauphinee SL, Williams JI, Maki B. Measuring balance in the elderly: validation of an instrument. Can J Public Health. 1992;83(Suppl 2):S7-S11.

23. Kaiser MJ, Bauer JM, Ramsch C, et al. Validation of the Mini Nutritional Assessment short-form (MNA®-SF): A practical tool for identification of nutritional status. J Nutr Health Aging. 2009;13(9):782-788.

24. Borson S, Scanlan JM, Watanabe J, Tu SP, Lessig M. Simplifying detection of cognitive impairment: comparison of the Mini-Cog and Mini-Mental State Examination in a multiethnic sample. J Am Geriatr Soc. 2005;53(5):871-874.

25. Campbell MJ, Machin D, Walters SJ. Medical Statistics: A Textbookfor the Health Sciences. Chichester: John Wiley \& Sons; 2010.

26. Westergren A, Khalaf A, Hagell P. A Swedish version of the SCREEN II for malnutrition assessment among community-dwelling elderly. Scand J Public Health. 2015;43(6):667-671.

27. Fonad E, Robins Wahlin TB, Rydholm Hedman AM. Associations between falls and general health, nutrition, dental health and medication use in Swedish home-dwelling people aged 75 years and over. Health Soc Care Community. 2015;23(6):594-604.

28. Gale CR, Cooper C, Aihie Sayer A, Sayer AA. Prevalence and risk factors for falls in older men and women: The English Longitudinal Study of Ageing. Age Ageing. 2016;45(6):789-794.

29. Machón M, Vergara I, Dorronsoro M, Vrotsou K, Larrañaga I. Selfperceived health in functionally independent older people: associated factors. BMC Geriatr. 2016;16(1):1.

30. Sherman H, Forsberg C, Karp A, Törnkvist L. The 75-year-old persons' self-reported health conditions: a knowledge base in the field of preventive home visits. J Clin Nurs. 2012;21(21-22):3170-3182.

31. Behm L, Wilhelmson K, Falk K, Eklund K, Zidén L, Dahlin-Ivanoff S. Positive health outcomes following health-promoting and diseasepreventive interventions for independent very old persons: long-term results of the three-armed RCT Elderly Persons in the Risk Zone. Arch Gerontol Geriatr. 2014;58(3):376-383.

32. Elwood P, Frost H, Haw S, Frank J. Interventions in community settings that prevent or delay disablement in later life: an overview of the evidence. Qual Ageing Older Adults. 2012;13(3):212-230.

33. Rizzuto D, Fratiglioni L. Lifestyle factors related to mortality and survival: a mini-review. Gerontology. 2014;60(4):327-335.

34. Tabue Teguo M, Simo-Tabue N, Stoykova R, et al. Feelings of loneliness and living alone as predictors of mortality in the elderly: the PAQUID study. Psychosom Med. 2016;78(8):904-909.

35. Dahlin-Ivanoff S, Gosman-Hedström G, Edberg AK, et al. Elderly persons in the risk zone. Design of a multidimensional, health-promoting, randomised three-armed controlled trial for "prefrail" people of $80+$ years living at home. BMC Geriatr. 2010;10(1):27.

36. Cereda E, Pedrolli C, Klersy C, et al. Nutritional status in older persons according to healthcare setting: A systematic review and meta-analysis of prevalence data using $\mathrm{MNA}^{\circledR}$. Clin Nutr. 2016;35(6):1282-1290.

37. Söderhamn U, Dale B, Sundsli K, Söderhamn O. Nutritional screening of older home-dwelling Norwegians: a comparison between two instruments. Clin Interv Aging. 2012;7:383.

38. Lagerin A, Carlsson AC, Nilsson G, Westman J, Törnkvist L. District nurses' preventive home visits to 75-year-olds: an opportunity to identify factors related to unsafe medication management. Scand J Public Health. 2014;42(8):786-794.

39. Wauters M, Elseviers M, Vaes B, et al. Polypharmacy in a Belgian cohort of community-dwelling oldest old: baseline observations and associated risk factors. Clin Ther. 2015;37(8):e8.

40. Petersen RC. Mild cognitive impairment. Continuum. 2016;22(2):404-418. 
41. Lindau M, Bjork R. Anosognosia and anosodiaphoria in mild cognitive impairment and Alzheimer's disease. Dement Geriatr Cogn Dis Extra. 2014;4(3):465-480.

42. Collard RM, Boter H, Schoevers RA, Oude Voshaar RC. Prevalence of frailty in community-dwelling older persons: a systematic review. $J$ Am Geriatr Soc. 2012;60(8):1487-1492.

43. Saliba D, Elliott M, Rubenstein LZ, et al. The Vulnerable Elders Survey: a tool for identifying vulnerable older people in the community. $\mathrm{J} \mathrm{Am}$ Geriatr Soc. 2001;49(12):1691-1699.
44. Vass M, Avlund K, Hendriksen C, Andersen CK, Keiding N. Preventive home visits to older people in Denmark: methodology of a randomized controlled study. Aging Clin Exp Res. 2002;14(6):509-515.

45. Sherman H, Söderhielm-Blid S, Forsberg C, Karp A, Törnkvist L. Effects of preventive home visits by district nurses on self-reported health of 75-year-olds. Prim Health Care Res Dev. 2016;17(1):56-71.

46. Waldinger RJ, Cohen S, Schulz MS, Crowell JA. Security of attachment to spouses in late life: Concurrent and prospective links with cognitive and emotional wellbeing. Clin Psychol Sci. 2015;3(4):516-529.
Journal of Multidisciplinary Healthcare

\section{Publish your work in this journal}

The Journal of Multidisciplinary Healthcare is an international, peerreviewed open-access journal that aims to represent and publish research in healthcare areas delivered by practitioners of different disciplines. This includes studies and reviews conducted by multidisciplinary teams as well as research which evaluates the results or conduct of such teams or health care processes in general. The journal covers a very wide range of areas and welcomes submissions from practitioners at all levels, from all over the world. The manuscript management system is completely online and includes a very quick and fair peer-review system. Visit http://www.dovepress.com/ testimonials.php to read real quotes from published authors. 